The International Journal of Indian Psychology

ISSN 2348-5396 (e) | ISSN: 2349-3429 (p)

Volume 5, Issue 1, DIP: 18.01.126/20170501

DOI: $10.25215 / 0501.126$

http://www.ijip.in | October-December, 2017

Article

\title{
Family Interaction Pattern and Quality Of Life of Caregivers Having Violent Patients with Bipolar Affective Disorder (Current Episode Mania)
}

\author{
Ashok. $\mathrm{S}^{1 *}$, Dr. Amool R Singh ${ }^{2}$
}

\section{ABSTRACT}

Background: Bipolar affective disorder (BAD) is a multi-factorial disorder with various clinical presentations. 'The manic episodes are manifestated by decreased sleep, irritability, aggression, dramatic fluctuation in mood or emotions caused to violent acts'. The clinical importance of hostility is in its close association with violence and non-adherence to treatment. BAD symptoms can result in damaged relationships, poor job or school performance that can seriously affect the lives of patients and their families. All caregivers share a similar fate; and they take responsibility for their mentally ill family members. Aim \& Objectives: Aim was to examine the family interaction pattern and quality of life of caregivers having violent patients with bipolar affective disorder (current episode mania). Methodology: The Present study was a cross sectional hospital based and approved by ethical committee. Total 858 family members/caregiver interviewed for history of violence with diagnosed patient with BAD current episode mania (age 21 - 45 years) fulfilling ICD-10 criteria selected using probability sampling, when they brought patient in OPD. Total thirty $(n=30)$ adult persons with BAD patient's caregivers sample were recruited as per inclusion, exclusion-criteria for data collection tools such as Semi-structured socio-demographic data sheet, Family Violence Scale (Bhatti et al., 1985), Family interaction pattern scale (Bhatti et al., 1986) and WHO-Quality of Life Scale (WHO-QoL-BREF, 1998). Results: There was no significant difference found in all domains of the Family Violence Scale. In correlation Physical violence domain positively correlated with Family Interaction Pattern's domain of Leadership pattern at 0.05 level \& Emotional violence positively correlated with Communication at 0.05 level and with Leadership pattern at 0.01 level. As well as Social violence positively correlated with the domain Leadership at 0.05 level. Also total score of family violence positively correlated with Leadership pattern at 0.01 level of the Family Interaction Pattern Scale. With QoL family violence domain emotional violence negatively correlated with the Psychological health, Social relationship and Environmental/Financial at

\footnotetext{
${ }^{1}$ Ph.D. Scholar, Department of Psychiatric Social Work, RINPAS, Kanke, India

${ }^{2}$ Professor, Department of Clinical Psychology, Ranchi Institute of Neuro Psychiatry and Allied Sciences, Kanke Ranchi, India

*Responding Author

(C) 2017 Ashok. S, A Singh; licensee IJIP. This is an Open Access Research distributed under the terms of the Creative Commons Attribution License (www.creativecommons.org/licenses/by/2.0), which permits unrestricted use, distribution, and reproduction in any Medium, provided the original work is properly cited.
} 


\section{Family Interaction Pattern and Quality Of Life of Caregivers Having Violent Patients with Bipolar Affective Disorder (Current Episode Mania)}

0.05 level and with Total score of QoL at 0.01 level. As well as total score of the family violence negatively correlated with the domain Social relationship at 0.05 level of the WHO Quality of life Scale. Conclusion: It is very important for the mental health professionals to identify the needs of the family caregivers. Finding out areas need attention and strategies to restore the wellbeing of an individual and caregiver requires knowledge and skill based comprehensive assessment. Mental health issues need multidimensional approaches to bring fruitful outcomes. Engagement and implementation strategies, as well as the interventions themselves, must be tailored to local and cultural characteristics.

Keywords: Bipolar Affective Disorder, Caregiver, Family Interaction Pattern, Quality Of Life And Violence.

Most psychiatric patients are not violent. Yet, there is a general consensus that severe mental illness, particularly bipolar disorder, does increase violence risk. Bipolar disorder (BD), also known as two poles of the continuum with manic-depressive illness, is a brain disorder that causes unusual shifts in mood, energy, activity levels, and the ability to carry out day-to-day tasks. 'Affective' means one's mood or emotions. The dramatic fluctuation in mood is sometimes referred to as an 'episode' or as a 'mood swing'. Bipolar Affective Disorder is an abnormal fluctuation in moods, varying between marked highs (mania) and lows (depression) with periods of stability. Bipolar affective disorder $(B A D)$ is a multi-factorial disorder with various clinical presentations. Extremely different moods such as mania, hypomania and depression cause sudden changes in behavior, feelings and thoughts. Due to having more manic symptoms of increased self-esteem or grandiosity, excessive engagement in pleasurable activities with a high risk of painful consequences, increased libido, hostility and Agitation. Impulsivity and aggression may be common during episodes they also cause alterations in the level of energy.

$>\quad$ The terms violence and aggression are used interchangeably, depending on context.

$>$ Agitation is excessive motor or verbal activity. Verbal aggression may include inarticulate shouts, abuse, or threats.

> Hostility denotes unfriendly attitudes. Overt irritability, anger, antipathy, or verbal aggression is manifestation of hostility. The clinical importance of hostility is in its close association with violence and non-adherence to treatment.

A factor analysis showed that aggression in bipolar disorder was associated with paranoia and irritability (Cassidy et al., 1998a). Thus, aggression is a feature of manic and mixed episodes of bipolar disorder, develops in the context of irritability, and may be an enduring individual trait. This irritable aggression remained stable in time across consecutive manic episodes (Cassidy et al., 2002).

According to Dore G (2001) study an impact of bipolar affective disorder on family and partner reveled, most commonly, caregivers were disturbed by aggressive and violent behaviors (17\%), suicidal ideas and acts, odd behaviors (10\%), over-activity, overtalkativeness, impulsive spends (each 4\%) and suicidal ideation and attempts. it was quite 


\section{Family Interaction Pattern and Quality Of Life of Caregivers Having Violent Patients with Bipolar Affective Disorder (Current Episode Mania)}

usual to have police involvement with patients during at least one episode of illness (66\%) and, although legal consequences were rare, it caused significant stress for many caregivers (Dore G, Romans SE., 2001).

The NESARC study conducted in 2001-2002 involved interviews to assess lifetime prevalence of aggressive behavior as well as the lifetime DSM-IV psychiatric disorders in 43,093 adults representing the population of the United States (Pulay et al., 2008). The lifetime prevalence of aggressive behavior after age 15 was $0.66 \%$ in persons without lifetime psychiatric disorder, but $25.34 \%$ and $13.58 \%$ in bipolar disorder I and II, respectively.

- $\quad$ The prevalence of aggressive behaviour in pure bipolar (without co-morbidity) was $2.52 \%$ and $5.12 \%$, respectively.

- The mean age at disorder onset is 18 years in bipolar - I disorder and 22 years in bipolar - II disorder (Merikangas et al., 2007).

- In India, Ganguli (2000) reported that the national rate of affective disorder was 34 per 1000 population.

According to World Health Organization is bipolar disorder the 12th most common disabling condition in the world for any age group causing moderate to severe impairment (WHO 2004).

Research indicates that bipolar disorders, major depressive disorders and schizophrenia could share biologic vulnerability and inheritance etiology (Van Snellenberg and de Candia 2009; Sidlova et al., 2011).

Earlier studies have further reported biological-environmental interaction is likely responsible for violence and aggression, careful attention must be paid to psychosocial factors that contribute to the development of violent behaviors. Beck (1999) asserts that aggressive individuals develop a cognitive framework containing basic flaws in perceptions of social interactions, so that the individual sees others as responsible for all of his or her problems.

Despite significant success in the pharmacological treatment, most bipolar patients cannot have drug treatment alone. Up to $50 \%$ of patients do not recover from acute manic episodes within one (1) year. Only 25\% of patients achieve full functional recovery. Mood stabilizers do not prevent about $20 \%$ to $40 \%$ of bipolar patients from disease relapse (Solomon et al., 1995 Moncrief 1995).

BAD compromises both family and personal relationships, lifestyle, work, education, healthcare and cognitive capabilities [Dore G, Romans SE (2001), Simon GE (2003), Pope M et al, (2007)].

Bipolar disorder is a recurrent and long term mental illness that can seriously affect the lives of patients and their families. It can place a heavy strain on families. People with severe 


\section{Family Interaction Pattern and Quality Of Life of Caregivers Having Violent Patients with Bipolar Affective Disorder (Current Episode Mania)}

mental illnesses are often dependent on family for care. However, in the psychiatric approach prevalent in the treatment of persons with $\mathrm{BAD}$, the medical attention is focused on the patient, while family members/caregivers do not receive sufficient consideration. Conceptualizing caregiver burden in a conventional medical framework may not focus enough on issues important to caregivers, or on cultural and social issues.

Subsequent research moved away from ambitious causal explanations to identify, within the framework of studies of expressed emotions, factors related to family interaction and family member's beliefs and expectations that are likely to influence the course of Bipolar disorder, schizophrenia and other mental and physical disorders (Leff and Vaughn, 1985).

During the last few decades, there has been an increase focus all over the world towards community care of psychiatric patients thus leading to an increase in care giving responsibility on family-members/caregivers. The mutual relationship between serious mental illness such as bipolar affective disorder (BAD) and the family system highlights the importance of adjunctive family interventions. On the other hand it is significant to know about the having violent persons with BAD and its relationship with family interaction and quality of life of caregivers hence, present study aimed to contributory in the literature.

\section{MATERIALS \& METHODS}

\section{Aim \& Objectives of study:}

To examine and compared family interaction pattern and quality of life of caregivers having violent patients with bipolar affective disorder (current episode mania).

1. To examine the violence of violent patients with bipolar affective disorder (mania) on caregivers.

2. To examine family interaction pattern among caregivers of violent patients with bipolar affective disorder (mania).

3. To assess the quality of life among caregivers of violent patients with bipolar affective disorder (mania).

Present study was conducted on caregiver's of person with Bipolar-Affective-Disorder (BAD) current episode mania at Out-Patient-department (OPD) of Ranchi Institute of Neuro Psychiatry \& Allied Sciences (RINPAS) Ranchi, Jharkhand. The study was approved by institutional Ethics Committee before of the study. A proper written informed consent was taken from all the participants of the study. It was a cross sectional study. A total 858 the family members/caregivers were interviewed for history of violence with diagnosed person with BAD current episode mania satisfying ICD-10 criteria age between 21 to 45 years and minimum two (2) years of illness duration was selected by using probability sampling.

At last Total of thirty $(n=30)$ caregivers age between 25 to 60 years of person with BAD sample were selected according to inclusion and exclusion criteria and explained about the aim and objectives of the study, those who will give the consent was selected for the study. 


\section{Family Interaction Pattern and Quality Of Life of Caregivers Having Violent Patients with Bipolar Affective Disorder (Current Episode Mania)}

Data collection tolls were administered on caregiver such as Semi-structured sociodemographic data sheet, Family Violence Scale (Bhatti et al., 1985), Family interaction pattern scale (Bhatti et al., 1986) and WHO-Quality of Life Scale BREF (WHO-QoL-BREF, 1998). The collected data further edit, coded and was entered in to Statistical Package for Social Sciences version-16 (SPSS-16) was used.

\section{Caregiver:}

According to das Changas Mederios Primary Caregiver those who "Responsibility for care of the patient is taken by the member of the family called the primary caregivers" (das Changas Mederios et al., 2000).

\section{Inclusion Criteria}

\section{For Patient's Group:}

1. Diagnosed cases of "Bipolar Affective Disorder with Mania" who fulfils ICD-10, DCR criteria with at least two (2) years total duration of illness.

2. Diagnosed patient's age range should be 21 to 45 years.

3. History of violent behaviour.

\section{For Caregivers:}

A. Primary Caregivers (parent, sibling, spouse, offspring, close key relative were the subjects).

$>\quad$ Both sexes between 25 to 60 years of age.

$>\quad$ Caregivers must be formal education up to $5^{\text {th }}$ standard.

$>\quad$ Caregivers must be providing care to their patient for at least one year.

$>\quad$ Caregivers those who are agreed to consent.

B. The caregiver provided care to the patient for at least one previous episode of mania and current episode.

\section{Exclusion criteria}

\section{Patient group}

1. Patient having with severe physical illness.

2. Patient having with substance dependence.

3. Patient having with severe co-morbid of organic and mental retardation.

\section{For caregivers}

A. The caregivers did not have any

1. Major physical illness.

2. Psychiatric illness.

B. The family did not have more than one patient suffering with either of mental illness or major physical illness. 


\section{Family Interaction Pattern and Quality Of Life of Caregivers Having Violent Patients with Bipolar}

Affective Disorder (Current Episode Mania)

\section{Instruments}

\section{1.'Semi-structured socio-demographic data sheet:}

The socio-demographic data sheet consist of two section, section-1 was information of the patient and section-2 was caregiver's, it included, age, gender, education, occupation, monthly income, religion, domicile, family type, marital status, duration of illness, duration of care providing and number of hospitalization \& adherence.

2. The Family Violence Scale (Bhatti et al., 1985) consists of five broad areas (A) i.e.

A1.Physical violence (15 items),

A2. Verbal violence - (2 items),

A3. Social violence - (5 items),

A4. Emotional violence - (5 items) and

A5. Intellectual violence - (5 items).

It is four point scale ranging from 0-3, 0- Not Applicable, 1- Mild, 2- Moderate, 3- Severe violence.

The family violence was defined as, an act performed by a family member to achieve the desired conformity that carries negative emotional component. Further, the various components in the scale clearly describe the domain of violence. Hence, it has a tremendous amount of content validity. Therefore, the tool is a reliable measure of family violence. The logical connection between the scale points and the concept of violence has already been explained Bhatti, 1989; Bhatti and Beig 1985. (Bhatti and Beig1985).

\section{Family Interaction Pattern Scale (FIPS) (Bhatti et al., 1986)}

Family Interaction Pattern Scale (FIPS) has been developed by Bhatti and his colleague in 1986 to measure the quality of family functioning. The scale has 106 items under 6 domains (D).

D1. Reinforcement,

D2. Social support system,

D3. Role,

D4. Communication,

D5. Cohesion and

D6. Leadership.

It is a four point Likert scale ranging from 1 - 4 and score varies from 106 - 424. Higher score shows dysfunction in that sub domain.

Studies of Bhatti and his colleague (1986) have shown the ability of scale to measure the dysfunction in the families of alcoholic, hysterical and depressive, and thus established its validity. It's inter-rating reliability and test re-test reliability is also established by Bhatti and his colleague (Bhatti, S.R. et al., 1986). 


\section{World Health Organization Quality of Life - BREF Scale, 1998}

The WHOQOL-BREF is a self-administered, multidimensional scale, it is an abbreviated version of WHO-QOL- 100 scale, containing 26 items each rated on a 5-point Likert scale. It measures quality of life in four (4) domains -

D1. Physical,

D2. Psychological,

D3. Social relationships,

D4. Environmental \& Financial resources and along with two items overall quality of life and overall general health facet.

Domain scores are scaled in a positive direction (i.e. higher scores denote higher QoL). The mean score of items within each domain is used to calculate the domain score. The scale has high internal consistency (Cronbach alpha - 0.94) (WHO-QoL- 1998).

\section{Procedure:}

The family members or caregivers were interviewed when they brought patient in OutPatient-department (OPD) of RINPAS. Caregivers were screened according to inclusion and exclusion criteria and explained about the aim and objectives of the study, those who will give the consent were recruited for the study. Subsequently data collection tolls administered on recruited sample.

\section{RESULTS}

Table -1: Socio-demographic parameters of person with Bipolar Affective Disorder (Mania)

\begin{tabular}{|c|c|c|c|c|c|}
\hline \multicolumn{2}{|c|}{ Variable } & \multirow{2}{*}{$\begin{array}{c}\begin{array}{c}\text { Bipolar } \\
\text { Affective } \\
\text { disorder } \\
(\mathbf{n}=30) \mathbf{n}(\%)\end{array} \\
17(56.7)\end{array}$} & \multirow{3}{*}{$\begin{array}{r}\chi^{2} \\
0.067\end{array}$} & \multirow{3}{*}{$\begin{array}{l}\text { df } \\
1\end{array}$} & \multirow{3}{*}{$\begin{array}{r}\mathbf{P} \\
0.795\end{array}$} \\
\hline \multirow[t]{2}{*}{ Sex of the patient } & Male & & & & \\
\hline & Female & $13(43.3)$ & & & \\
\hline \multirow[t]{5}{*}{ Age of the patient } & 21 to 25 yrs & $11(36.7)$ & \multirow[t]{5}{*}{4.469} & \multirow[t]{5}{*}{4} & \multirow[t]{5}{*}{0.346} \\
\hline & 26 to 30 yrs & $6(20)$ & & & \\
\hline & 31 to 35 yrs & $5(16.7)$ & & & \\
\hline & 36 to 40 yrs & $4(13.3)$ & & & \\
\hline & 41 to 45 yrs & $4(13.3)$ & & & \\
\hline \multirow[t]{6}{*}{ Education } & Illiterate & $2(6.7)$ & \multirow{6}{*}{4.710} & \multirow{6}{*}{5} & \multirow{6}{*}{0.452} \\
\hline & Primary & $5(16.7)$ & & & \\
\hline & Secondary & $13(43.3)$ & & & \\
\hline & Intermediate & $6(20)$ & & & \\
\hline & Graduation & $3(10)$ & & & \\
\hline & Post Graduation & $1(3.3)$ & & & \\
\hline \multirow[t]{3}{*}{ Occupation } & Farmer/Laborer & $1(3.3)$ & \multirow[b]{3}{*}{4.412} & \multirow[b]{3}{*}{5} & \multirow[b]{3}{*}{0.492} \\
\hline & Business & $3(10.0)$ & & & \\
\hline & Govt Employee & $1(3.3)$ & & & \\
\hline
\end{tabular}


Family Interaction Pattern and Quality Of Life of Caregivers Having Violent Patients with Bipolar Affective Disorder (Current Episode Mania)

\begin{tabular}{|c|c|c|c|c|c|}
\hline \multicolumn{2}{|c|}{ Variable } & $\begin{array}{c}\text { Bipolar } \\
\text { Affective } \\
\text { disorder } \\
(\mathbf{n}=30) \mathbf{n}(\%)\end{array}$ & $\chi^{2}$ & df & $\mathbf{P}$ \\
\hline & Housewife & $12(40)$ & & & \\
\hline & Unemployed & $12(40)$ & & & \\
\hline & Others & $1(3.3)$ & & & \\
\hline \multirow[t]{3}{*}{ Family type } & Nuclear & $15(50)$ & \multirow{3}{*}{3.273} & \multirow{3}{*}{2} & \multirow{3}{*}{3.273} \\
\hline & Joint & $12(40)$ & & & \\
\hline & Extended & $3(10.0)$ & & & \\
\hline \multirow[t]{3}{*}{ Domicile } & Rural & $14(46.7)$ & \multirow{3}{*}{1.109} & \multirow{3}{*}{2} & \multirow{3}{*}{0.575} \\
\hline & Suburban & $7(23.3)$ & & & \\
\hline & Urban & $9(30)$ & & & \\
\hline \multirow[t]{3}{*}{ Religion } & Hindu & $25(83.3)$ & \multirow{3}{*}{1.11} & \multirow{3}{*}{1} & \multirow{3}{*}{0.739} \\
\hline & Muslim & $5(16.7)$ & & & \\
\hline & Christian & $0(0)$ & & & \\
\hline \multirow[t]{3}{*}{ Category } & General & $7(23.3)$ & \multirow{3}{*}{0.833} & \multirow{3}{*}{2} & \multirow{3}{*}{0.659} \\
\hline & OBC & $20(66.7)$ & & & \\
\hline & Tribal/ SC & $3(10)$ & & & \\
\hline \multirow[t]{3}{*}{ Marital status } & Unmarried & $9(30)$ & \multirow{3}{*}{1.506} & \multirow{3}{*}{2} & \multirow{3}{*}{0.471} \\
\hline & Married & $20(66.7)$ & & & \\
\hline & Divorce/Separate & $1(3.3)$ & & & \\
\hline
\end{tabular}

Present study table (1) showing there were not found significant different in sociodemographic variables of patient.

Table -2: Caregiver's Socio-demographic parameters of Bipolar Affective Disorder (Mania)

\begin{tabular}{|c|c|c|c|c|c|}
\hline \multicolumn{2}{|l|}{ Variable } & \multirow{2}{*}{\begin{tabular}{ll} 
Bipolar & \multicolumn{2}{c|}{ Affective } \\
disorder & $(\mathrm{n}=30)$ \\
$(\%)$ & \\
$24(80)$ & \\
\end{tabular}} & \multirow{4}{*}{$\begin{array}{l}\chi^{2} \\
2.080\end{array}$} & \multirow{4}{*}{\begin{tabular}{|l|} 
Df \\
2 \\
\end{tabular}} & \multirow{4}{*}{$\begin{array}{l}\mathbf{p} \\
0.353\end{array}$} \\
\hline \multirow{3}{*}{$\begin{array}{l}\text { Relation with } \\
\text { patient }\end{array}$} & Parent/Spouse & & & & \\
\hline & Sibling & $0(0)$ & & & \\
\hline & Others & $6(20)$ & & & \\
\hline \multirow{2}{*}{$\begin{array}{l}\text { Sex of the } \\
\text { Caregiver }\end{array}$} & Male & $24(80)$ & \multirow[t]{2}{*}{0.111} & \multirow[t]{2}{*}{1} & \multirow[t]{2}{*}{0.739} \\
\hline & Female & $6(20)$ & & & \\
\hline \multirow{6}{*}{ Education } & Illiterate & $0(0)$ & \multirow{6}{*}{5.637} & \multirow{6}{*}{4} & \multirow{6}{*}{0.228} \\
\hline & Primary & $9(30)$ & & & \\
\hline & Secondary & $14(46.7)$ & & & \\
\hline & Intermediate & $3(10)$ & & & \\
\hline & Graduation & $3(10)$ & & & \\
\hline & Post Graduation & $1(3.3)$ & & & \\
\hline \multirow{6}{*}{ Occupation } & Farmer/Laborer & $9(30)$ & \multirow{6}{*}{1.400} & \multirow{6}{*}{5} & \multirow{6}{*}{0.924} \\
\hline & Business & $7(23.3)$ & & & \\
\hline & Govt Employee & $1(3.3)$ & & & \\
\hline & Housewife & $6(20)$ & & & \\
\hline & Unemployed & $1(3.3)$ & & & \\
\hline & Others & $1(3.3)$ & & & \\
\hline
\end{tabular}

(C) The International Journal of Indian Psychology, ISSN 2348-5396 (e)| ISSN: 2349-3429 (p) | 59 
Family Interaction Pattern and Quality Of Life of Caregivers Having Violent Patients with Bipolar Affective Disorder (Current Episode Mania)

\begin{tabular}{|l|l|l|l|l|l|}
\hline \multirow{2}{*}{ Family type } & Nuclear & $15(50)$ & \multirow{3}{*}{3.273} & 2 & \multirow{2}{*}{3.273} \\
\cline { 2 - 3 } & Joint & $12(40)$ & & & \\
\cline { 2 - 3 } $\begin{array}{l}\text { Socio Economic } \\
\text { Status }\end{array}$ & Extended & $3(10.0)$ & & & \\
& Low & $28(93.3)$ & $2(6.7)$ & 2 & 0.513 \\
\cline { 2 - 3 } & Middle & $0(0)$ & & & \\
\cline { 2 - 3 } & Higher & 0.533 & \\
\hline
\end{tabular}

Present study table-2 showing there were not found significant different in sociodemographic variables of caregiver.

Table-3: Comparison of the Family Violence between Male and Female gender of Bipolar Affective disorder (Mania)

\begin{tabular}{|c|c|c|c|c|c|}
\hline Variable & & Bipolar & & & \\
\hline $\begin{array}{l}\text { Family- } \\
\text { Violence } \\
\text { Scale }\end{array}$ & $\begin{array}{l}\text { Sex of the } \\
\text { patient }\end{array}$ & $\begin{array}{l}\text { Affective } \\
\text { disorder } \\
(\text { Mean } \pm \text { SD) } \\
(n=30)\end{array}$ & $\mathbf{T}$ & Df & $\mathbf{p}$ \\
\hline \multirow{2}{*}{$\begin{array}{l}\text { Physical } \\
\text { Violence }\end{array}$} & Male & $16.82 \pm 7.91$ & \multirow[t]{2}{*}{0.421} & \multirow[t]{2}{*}{28} & \multirow[t]{2}{*}{0.677} \\
\hline & Female & $15.76 \pm 4.90$ & & & \\
\hline \multirow{2}{*}{$\begin{array}{l}\text { Verbal } \\
\text { Violence }\end{array}$} & Male & $4.35 \pm 1.41$ & \multirow[t]{2}{*}{0.685} & \multirow[t]{2}{*}{28} & \multirow[t]{2}{*}{0.499} \\
\hline & Female & $4.69 \pm 1.25$ & & & \\
\hline \multirow{2}{*}{$\begin{array}{l}\text { Emotional } \\
\text { Violence }\end{array}$} & Male & $7.17 \pm 3.94$ & \multirow[t]{2}{*}{0.357} & \multirow[t]{2}{*}{28} & \multirow[t]{2}{*}{0.724} \\
\hline & Female & $7.69 \pm 3.90$ & & & \\
\hline \multirow{2}{*}{$\begin{array}{l}\text { Social } \\
\text { Violence }\end{array}$} & Male & $9.11 \pm 4.22$ & \multirow[t]{2}{*}{0.719} & \multirow[t]{2}{*}{28} & \multirow[t]{2}{*}{0.478} \\
\hline & Female & $10.30 \pm 4.82$ & & & \\
\hline \multirow{2}{*}{$\begin{array}{l}\text { Intellectual } \\
\text { Violence }\end{array}$} & Male & $8.05 \pm 3.63$ & \multirow[t]{2}{*}{1.284} & \multirow[t]{2}{*}{28} & \multirow[t]{2}{*}{0.210} \\
\hline & Female & $6.31 \pm 3.79$ & & & \\
\hline \multirow{2}{*}{$\begin{array}{l}\text { Total Score } \\
\text { of Family } \\
\text { Violence } \\
\text { Scale }\end{array}$} & Male & $45.53 \pm 15.05$ & \multirow[t]{2}{*}{1.42} & \multirow[t]{2}{*}{28} & \multirow[t]{2}{*}{0.888} \\
\hline & Female & $44.77 \pm 13.81$ & & & \\
\hline
\end{tabular}

Significant at $P \leqq 0.01 * *$; Significant at $P \leq 0.05 *$.

Present study table-3 showing comparison of family violence scores between male and female gender, there was no significant difference found in all domains of both gender.

Table-4 : Correlation between the Family Violence and Family Interaction Pattern of Bipolar Affective disorder (Mania)

\begin{tabular}{|l|l|l|l|l|l|l|l|}
\hline Variable & \multicolumn{3}{|l|}{ Family Interaction Pattern Scale } \\
\hline $\begin{array}{l}\text { Family- } \\
\text { Violence }\end{array}$ & Value & Reinforce- & Social- & Role & Communi- & Cohesion & Leader- \\
\hline
\end{tabular}


Family Interaction Pattern and Quality Of Life of Caregivers Having Violent Patients with Bipolar Affective Disorder (Current Episode Mania)

\begin{tabular}{|c|c|c|c|c|c|c|c|}
\hline \multirow{2}{*}{$\begin{array}{l}\text { Variable } \\
\text { Scale }\end{array}$} & \multicolumn{7}{|c|}{ Family Interaction Pattern Scale } \\
\hline & & ment & Support & & cation & & Ship \\
\hline \multirow{2}{*}{$\begin{array}{l}\text { Physical } \\
\text { Violence }\end{array}$} & r-value & -0.080 & -0.246 & 0.159 & 0.048 & 0.068 & 0.370* \\
\hline & p-value & 0.673 & 0.190 & 0.401 & 0.800 & 0.721 & 0.044 \\
\hline \multirow{2}{*}{$\begin{array}{l}\text { Verbal } \\
\text { Violence }\end{array}$} & r-value & -0.007 & 0.000 & 0.099 & 0.157 & 0.104 & 0.187 \\
\hline & p-value & 0.970 & 1.000 & 0.604 & 0.407 & 0.584 & 0.322 \\
\hline \multirow{2}{*}{$\begin{array}{l}\text { Emotional } \\
\text { Violence }\end{array}$} & r-value & -0.070 & -0.199 & 0.150 & 0.393* & 0.184 & $0.645^{* *}$ \\
\hline & p-value & 0.714 & 0.531 & 0.430 & 0.031 & 0.331 & 0.000 \\
\hline \multirow{2}{*}{$\begin{array}{l}\text { Social } \\
\text { Violence }\end{array}$} & r-value & -0.006 & 0.113 & 0.275 & 0.133 & 0.033 & 0.409* \\
\hline & p-value & 0.975 & 0.553 & 0.142 & 0.483 & 0.865 & 0.025 \\
\hline \multirow{2}{*}{$\begin{array}{l}\text { Intellectual } \\
\text { Violence }\end{array}$} & r-value & -0.305 & 0.110 & -0.214 & -0.282 & -0.217 & -0.017 \\
\hline & p-value & 0.102 & 0.563 & 0.256 & 0.131 & 0.250 & 0.928 \\
\hline \multirow{2}{*}{$\begin{array}{c}\text { Total } \\
\text { Score } \\
\text { of Family } \\
\text { Violence } \\
\text { Scale }\end{array}$} & r-value & -0.139 & -0.084 & 0.154 & 0.111 & 0.045 & $0.488 * *$ \\
\hline & p-value & 0.464 & 0.660 & 0.417 & 0.558 & 0.815 & 0.006 \\
\hline
\end{tabular}

Correlation at Significant $P \leq 0.01 * *$; Significant at $P \leq 0.05 *$ level (two-tailed)

Present study (table-4) findings indicate that physical violence domain positively correlated with family interaction pattern's domain of leadership pattern at 0.05 level. Another domain emotional violence positively correlated with communication at 0.05 level and with leadership pattern at 0.01 level. As well as social violence positively correlated with the domain leadership at 0.05 level. Also total score of family violence positively correlated with leadership pattern at 0.01 level of the family interaction pattern scale.

Table-5: Correlation between the Family Violence and WHO - Quality of Life (QoL) of Bipolar Affective disorder (Mania)

\begin{tabular}{|c|c|c|c|c|c|c|}
\hline \multirow{2}{*}{$\begin{array}{l}\text { Variable } \\
\text { Family- } \\
\text { Violence } \\
\text { Scale }\end{array}$} & \multicolumn{6}{|c|}{ WHO - Quality of Life (QoL) } \\
\hline & Value & $\begin{array}{l}\text { Physical- } \\
\text { Health }\end{array}$ & $\begin{array}{l}\text { Psychological- } \\
\text { Health }\end{array}$ & Social & $\begin{array}{l}\text { Environmental/ } \\
\text { Financial }\end{array}$ & $\begin{array}{l}\text { Total Score } \\
\text { of Quality of } \\
\text { Life }\end{array}$ \\
\hline \multirow{2}{*}{$\begin{array}{l}\text { Physical } \\
\text { Violence }\end{array}$} & r-value & -0.176 & -0.167 & -0.306 & -0.031 & -0.174 \\
\hline & $\mathrm{p}$-value & 0.353 & 0.379 & 0.100 & 0.873 & 0.358 \\
\hline \multirow{2}{*}{$\begin{array}{l}\text { Verbal } \\
\text { Violence }\end{array}$} & r-value & 0.004 & -0.188 & -0.031 & -0.185 & -0.152 \\
\hline & p-value & 0.984 & 0.319 & 0.870 & 0.329 & 0.422 \\
\hline \multirow{2}{*}{$\begin{array}{l}\text { Emotional } \\
\text { Violence }\end{array}$} & r-value & -0.311 & $-0.420^{*}$ & $-0.388^{*}$ & $-0.461 *$ & $-0.510 * *$ \\
\hline & p-value & 0.094 & 0.021 & 0.034 & 0.010 & 0.004 \\
\hline \multirow{2}{*}{$\begin{array}{l}\text { Social } \\
\text { Violence }\end{array}$} & r-value & -0.298 & -0.263 & -0.360 & -0.242 & -0.348 \\
\hline & p-value & 0.110 & 0.160 & 0.051 & 0.197 & 0.059 \\
\hline
\end{tabular}

(C) The International Journal of Indian Psychology, ISSN 2348-5396 (e)| ISSN: 2349-3429 (p) | 61 


\begin{tabular}{|l|l|l|l|l|l|l|}
\hline \multirow{2}{\text{Variable}}{} & \multicolumn{6}{|l|}{ WHO - Quality of Life (QoL) } \\
\hline $\begin{array}{l}\text { Family- } \\
\text { Violence } \\
\text { Scale }\end{array}$ & Value & $\begin{array}{l}\text { Physical- } \\
\text { Health }\end{array}$ & $\begin{array}{l}\text { Psychological- } \\
\text { Health }\end{array}$ & Social & $\begin{array}{l}\text { Environmental/ } \\
\text { Financial }\end{array}$ & $\begin{array}{l}\text { Total Score } \\
\text { of Quality of } \\
\text { Life }\end{array}$ \\
\hline $\begin{array}{l}\text { Intellectual } \\
\text { Violence }\end{array}$ & r-value & 0.320 & 0.352 & -0.001 & 0.306 & 0.342 \\
\cline { 2 - 7 } & p-value & 0.085 & 0.057 & 0.994 & 0.100 & 0.064 \\
\hline $\begin{array}{l}\text { Total Score } \\
\text { of Family } \\
\text { Violence } \\
\text { Scale }\end{array}$ & r-value & -0.175 & -0.199 & $-\mathbf{0 . 3 6 4 *}$ & -0.152 & -0.253 \\
\cline { 2 - 7 } & p-value & 0.354 & 0.292 & 0.048 & 0.424 & 0.178 \\
\hline
\end{tabular}

Correlation at Significant $P \leqq 0.01 * *$; Significant at $P \leq 0.05 *$ level (two-tailed)

Present study (table-5) findings indicates that emotional violence domain negatively correlated with the domains psychological health, social relationship and environmental/financial at 0.05 level and also total score of quality of life at 0.01 level. As well as total score of the family violence negatively correlated with social relationship domain at 0.05 level of the quality of life.

\section{DISCUSSION}

Social and cultural changes have altered entire lifestyles, interpersonal relationship patterns, power structures and familial relationship arrangements in current times. These changes have increased the stress and pressure on such families, leading to an increased vulnerability to emotional problems and disorders. Family members of those with bipolar affective disorder really struggle. In India, as well as in most of the nonwestern world, and in other parts of the world, families have been the mainstay of care-giving for persons with mental illnesses. In view of the fact that violence is a complex behavior related not only to clinical factors (such as paranoid states, drug abuse, and command hallucinations) but also to social factors (such as economics, social stability, culture, and religion) and systems of psychiatric care, it is particularly important to investigate the aggressive and violent behavior of psychiatric patients across different countries.

\section{Socio-demographic characteristics of both Patient and Caregiver-}

Considering different socio-demographic variables of patient about sex 56.7\% were males while $43.3 \%$ were females. Patients were selected age between 21 to 45 years and categorized into five (5) groups. The mean age of the patients 21 to 25 yrs was $36.7 \%, 26$ to 30 yrs was $20 \%$, 30 to 35 yrs was $16.7 \%, 36$ to 40 yrs was $13.3 \%$ and 40 to 45 yrs was $13.3 \%$. In this present study, sex was not found significant. Present study most of them low level of education standard up-to secondary $43.3 \%$ and intermediate $20 \%$ also regarding occupation $40 \%$ were unemployed and $40 \%$ house wives. As well as caregiver's education was most of them low level of education standard up-to secondary $46.7 \%$ and primary education $30 \%$, about occupation most of them farmer 30\% and small-business $23.3 \%$, when considering to socio economic status most of them belongs to $93.3 \%$ Low socio economic status. Previous 


\section{Family Interaction Pattern and Quality Of Life of Caregivers Having Violent Patients with Bipolar Affective Disorder (Current Episode Mania)}

study of Stanton B et al., (1997) perceived that among women and men under 45 years of age, those in the lowest socioeconomic class were three times more likely to be violent than those in the highest socioeconomic class. Rates of violence also increased with lower education level, less social stability, and in regions with high rates of unemployment. Other variables patient's Family type most of them was nuclear family $50 \%$ and joint family $40 \%$ and about domical most them healing from rural $46.7 \%$, urban $30 \%$ and suburban $23.3 \%$. Regarding marital status most of them married 66.7\%, Unmarried 30\% most of them belongs to Hindu religion 83.3\%, Muslims 16.7\%. In a review of literature, Bonta, et al., (1998) found that younger age, male sex, single marital status, and having antisocial peers were associated with violent recidivism. Most evidence shows that race and social class are unrelated to recurrence of violence. Indeed, other studies observed that nuclear family structure is more prone to mental disorders than joint families (Sethi BB, et al ., 1985).

\section{In relation to family violence:}

The family caregivers bear with the behavioral disturbances of the ill family members and sometimes can also be a target of the patient's abusive or violent behavior. The present study results revealed that both male and female sex there was no significant difference found in all domains of the Family Violence Scale. Although the observation of mean score of physical violence by males were slightly high 16.82 than females 15.76, also intellectual violence by males were high mean score 8.05 than females 6.31. While other areas of verbal, emotional and social violence was found in females were slightly high than males. On the other hand, the overall total score of family violence by males were slightly high 45.53 than females 44.77. Earlier studies Fottrel1 (1980), Tardiff and Sweillam (1982), Krakowski et al. (1989), James et al.(1990) and Walker and Seifert (1994) have not found significant differences in violence rates between male and female psychiatric inpatients. Other previous studies have supported the similar findings. Larkin et al. (1988) and Nobel and Rodger (1989) found women more assaultive than men. In contrast, several studies on psychiatric outpatients reported that men were more violent than women [(Tardiff K, et al., 1980), (McNiel DE, et al., 1988), (Krakowshi M, et al., 1989)]. Tardiff and Koenigsberg (1985) suggested it has been that psychiatric outpatients and inpatients may show a different kind of violent behavior and that distinct factors may be related to violent behavior inside and outside hospital (Rofman ES, et al., 1980).

\section{Observing into family interaction pattern}

Family relationship means relatedness or connection by blood or marriage or adoption. It also indicates when people relate with each other with kinship or relationship. As a result of that it is commonly recognized that certain conditions of family life, especially certain forms of family interactions may predispose a family member to mental illness. Current study findings indicate that in Physical violence domain positively correlated with Family Interaction Pattern's domain of Leadership pattern at 0.05 level. Another domain Emotional violence was positively correlated with Communication at 0.05 level and with Leadership pattern at 0.01 level, as well as Social violence positively correlated with the domain Leadership at 


\section{Family Interaction Pattern and Quality Of Life of Caregivers Having Violent Patients with Bipolar Affective Disorder (Current Episode Mania)}

0.05 level. Also total score of family violence positively correlated with Leadership pattern at 0.01 level of the Family Interaction Pattern Scale. Present study findings suggesting that caregivers who had dominating leadership traits giving rise to the physical, emotional and social violence in the patient. Farther dominating leadership traits giving rise to the overall total violence in the patient. As well as unhealthy/ faulty communication pattern also giving raise to emotional violence in patient with bipolar affective disorder. Leadership is a family member engaged in decision making through consensus for the growth of the family as a system is the leader of the family. The manner of working of leaders is roughly called as 'leadership style'. Leadership style is the manner and approach of providing direction, implementing plans, and motivating people. In this context, researchers have also tried to define dysfunctional families.

Considering into family system there are many types of parenting styles based on family leadership style. Earlier studies emphasized on family leadership styles, according to Baumrind, (1971, 1997) emphasized about Authoritarian Parenting Style contains strong parental command over their child, leaving minimal input of the child in decisions or rationales. Further, in this form of one-way communication and expect their orders to be obeyed without explanation. In contrast, authoritative-reciprocal parenting as described by Baumrind, contributes to better self-esteem, social responsibility, and academic performance. Stefos G et al ., (1996) in a longitudinal follow-up study in bipolar patients, concluded that poor quality of relationships with extended family and low level of social support significantly predicted the occurrence of a major affective episode. Chang et al., (2001;1999) demonstrated that families of patients with Bipolar Disorder reported more conflicts, less organization and less cohesion compared to control group, as measured by family interaction pattern scale. Johnson JG et al., (2001) studied on association of maladaptive parental behavior with psychiatric disorder among parents and their offspring and revealed maladaptive parental behavior is associated with an increased risk for the development of psychiatric disorders among the offspring of parents with and without psychiatric disorders. Another important construct in relation to family interaction pattern is "Communication process", which describes the communication is a process through which the family members convey their feelings, emotions and personal views.

Earlier studies have supported the similar findings. According to Miklowitz, D. J. et al., (1991) on communication deviance/difference (CD) in families of manic patients and schizophrenic revealed that elevated levels of communication deviance (CD) have been found in parents of patients with bipolar disorder. Also perceived during the interactions used to assess communication deviance, manic patients, as well as their parents, demonstrated odd word usage and unusually constructed sentences more frequently than schizophrenia patients. So this communication deviance/difference leads to emotional imbalance, this emotional disturbance causes to anger outburst or violence towards caregivers. Finally, it is necessary to consider family in its social context, Family would be a dynamic system affected by its subsystems and by external systems with a continuous input and output of information. In 


\section{Family Interaction Pattern and Quality Of Life of Caregivers Having Violent Patients with Bipolar Affective Disorder (Current Episode Mania)}

some cases, family burden generates a closure in its external and internal limits to prevent family from changing.

\section{In relation to Quality of Life (QoL)}

WHO-Quality of life (1998) is defined as “individuals' perceptions of their position in life in the context of the culture and value systems in which they live and in relation to their goals, expectations, standards and concerns". Care giving for mentally ill patient impacts on various aspects of a caregiver's over all life, including his or her physical, emotional and psychological health. Present study results indicates that in family violence domain emotional violence negatively correlated with the domain Psychological health, Social relationship and Environmental/Financial at 0.05 level and with Total score of Quality of life at 0.01 level. As well as total score of the family violence negatively correlated with the domain Social- relationship at 0.05 level of the WHO - Quality of life Scale. Findings suggest that if emotional violence of the patient affects psychological health, social relationships and environmental/ financial recourses of the caregivers quality of life adversely. Recant study In the West, Hirst (2005) has found that burden of family caregivers of the chronic mentally ill does impact their financial, physical, emotional, and psychological health. Being a long-term caregiver has been found to be associated with a variety of negative outcomes. The compromise among studies examining physical and mental health outcomes is that a majority of caregivers report feeling physically and emotionally distressed (Anthony-Bergstone C.R. et al., 1988; Clipp EC, et al., 1990). Several studies report higher levels of psychological morbidity among caregivers compared to non care-giving samples of the populations. Anthony- Bergstone and her colleagues (1988) noted the increased feeling of hostility, anger, and anxiety among caregivers as compared to the general population.

Literature would suggest that caregivers experience greater burden and distress when patients are more symptomatic. For instance, Perlick et al. (2001a) found that the level of burden reported by caregivers of bipolar and schizophrenic patients increased in relation to total patient symptom severity, and Dore and Romans (2001) found that caregivers tended to be significantly distressed by the way the patient related to them when unwell. Perlick et al. (2007) found that the experience of burden was related to depression in the caregivers of bipolar patients. However, in our sample, caregivers who reported less anxiety were linked to patients that were more depressed, more anxious, and reported worse life quality and therapeutic alliance.

\section{CONCLUSION}

Violence has serious implications for society and psychiatric practice, directly and indirectly affecting the quality of life of patients, their families, the community, and mental health workers. Present study highlighted that family interaction patterns and communication are potential interpersonal variables that determine level of interpersonal violence in families with patients having BAD. It is very important for the mental health professionals to identify the needs of the family caregivers. Finding out areas need attention and strategies to restore 


\section{Family Interaction Pattern and Quality Of Life of Caregivers Having Violent Patients with Bipolar Affective Disorder (Current Episode Mania)}

the wellbeing of an individual and caregiver requires knowledge and skill based comprehensive assessment. Mental health issues need multidimensional approaches to bring fruitful outcomes. Engagement and implementation strategies, as well as the interventions themselves, must be tailored to local and cultural characteristics. Potential short-term interventions can be provided at the time of hospitalization for families of patients with mood disorders on aspects pertaining to interpersonal communication and interaction pattern which ensures better recovery of patients and families, limits incidence of violence and improves quality of life of patient as well as caregivers.

\section{REFERENCES}

Anthony-Bergstone C.R., Zarit S.H., Gatz M. Symptoms of psychological distress among caregivers of dementia patients. Psychol Aging. 1988;3:245-248.

Anthony-Bergstone C.R., Zarit S.H., Gatz M. Symptoms of psychological distress among caregivers of dementia patients. Psychol Aging. 1988;3:245-248.

Baumrind D. Current patterns of parental authority. Dev Psychol Monogr. 1971;4:1-103.

Beck A. Prisoners of Hate: The Cognitive Basis of Anger, Hostility, and Violence. New York: HarperCollins; 1999.

Bhatti R, Beig A. Family violence: A systemic model. Indian J Soc Psychiatry. 1985;1:17485.

Bhatti, S.R., Cuba, K.D.K., Benedicta., L.A. (1986) Validation of Family Interaction Pattern Scale. Indian Journal of Psychiatry, 28, 211-216

Bonta J, Law M, Hanson K. The prediction of criminal and violent recidivism among mentally disordered offenders: a meta-analysis Psychological Bull. 1998123123-142 [PubMed]

Cassidy F, Forest K, Murry E \& Carroll BJ: A factor analysis of the signs and symptoms of mania. Archives of General Psychiatry 1998a; 55:27-32.

Cassidy F, Yatham LN, Berk M, Grof P: Pure and mixed manic subtypes: a review, Bipolar Disord 2002-;10:131-143.

Chang, K., Blasey, C., Ketter, T., \& Steiner, H. (2001). Family environment of children and adolescents with bipolar parents. Bipolar Disorders, 3(2), 73-78.

Clipp EC, George LK. Psychotropic drug use among caregivers of patients with dementia. Journal of the American Geriatric Society. 1990;38:227-235.

Das Changas Mederios, M.M., Ferraz, M.B., Quaresma, M.R., 2000 The effect of Rheumatoid arthritis on the quality of Primary Caregivers. Journal of Rheumatology 27, 76- 83

Dore G, Romans SE. Impact of bipolar affective disorder on family and partners. J Affect Disord.2001;67:147-158. [PubMed]

Fottrell E (1980) A study of violent behavior among patients in psychiatric hospitals. $\mathrm{Br} \mathrm{J}$ Psychiatry 136:216-221

Ganguli, H C. Epidemiological findings on prevalence of mental disorders in India.Indian J Psychiatry.42 (1) ,2000,14-20. 


\section{Family Interaction Pattern and Quality Of Life of Caregivers Having Violent Patients with Bipolar Affective Disorder (Current Episode Mania)}

Hirst M. Carer distress: a prospective, population-based study. Soc Sci Med. 2005;61(3):697_ 708.

James DV, Fineberg NA, Shah AK, Priest RG (1990) An increase in violence on an acute psychiatric ward. A study of associated factors. Br J Psychiatry 156:846-852

Johnson JG, Cohen P, Kasen S, Smailes E, Brook JS. Association of maladaptive parental behavior with psychiatric disorder among parents and their offspring. Arch Gen Psychiatry. 2001;58:453-60. [PubMed]

Krakowski M, Convit A, Jaeger J, et al (1989) "Neurological Impairment in Violent Schizophrenic Inpatients," American Journal of Psychiatry 146:849853, 1989

Krakowski MI, Convit A, Jaeger J, et al. (1989) Inpatient violence: trait and state. J Psychiatr Res 23:57-64

Larkin E, Murtagh S, Jones S (i988) A preliminary study of violent incidents in a special hospital (Rampton) Br J Psychiatry 153: 226-231

Leff J, Vaughn C. Expressed Emotion in Families. New York: Guilford Press; 1985.

McNiel DE, Binder RC, Greenfield TK (1988) Predictors of violence in committed acute psychiatric patients. Am J Psychiatry 145:965-970

Merikangas KR, Akiskal HS, Angst J, Greenberg PE, Hirschfeld RM, Petukhova M, Kessler RC (2007). Lifetime and 12-month prevalence of bipolar spectrum disorder in the National Comorbidity Sur vey replication [published correction appears in Arch Gen Psychiatry. 64(9): 1039]. Arch Gen Psychiatry. 64(5): 543-552.

Miklowitz, D. J., Goldstein, M. J. \& Nuechterlein, K. H. (1991). Verbal interactions in the families of schizophrenic and bipolar affective patients. Journal of Abnormal Psychology, 104, 268-276.

Nobel P, Rodger S (1989) Violence by psychiatric in-patients. Br J Psychiatry 155:384-390 McNiel DE, Binder RC, Greenfield TK (1988) Predictors of vio- lence in committed acute psychiatric patients. Am J Psychiatry 145:965-970

Perlick DA, Rosenheck RA, Miklowitz DJ, Chessick C, Wolff N, Kaczynski R, Ostacher M, Patel J, Desai R; STEP-BD Family Experience Collaborative Study Group (2007) Prevalence and correlates of burden among caregivers of patients with bipolar disorder enrolled in the Systematic Treatment Enhancement Program for Bipolar Disorder. Bipolar Disord. 9:262-273.

Pope M, Dudley R, Scott J. Determinants of social functioning in bipolar disorder. Bipolar Disord.2007; 9:38-44. [PubMed]

Pulay AJ, Dawson DA, Hasin DS, Goldstein RB, Ruan WJ, Pickering RP, Huang B, Chou SP \& Grant BF (2008): Violent Behavior and DSM-IV Psychiatric Disorders: Results From the National Epidemiologic Survey on Alcohol and Related Conditions. J Clin Psychiatry 2008; 69:12-22.

Rofman ES, Askinazi C, Fant E (1980) The prediction of dangerous behavior in emergency civil commitment. Am J Psychi- atry 137:1061-1064

Sethi BB, Chaturvedi PK. A review and role of family studies and mental health. Indian J Soc Psychiatry. 1985;1:216-30 


\section{Family Interaction Pattern and Quality Of Life of Caregivers Having Violent Patients with Bipolar}

Affective Disorder (Current Episode Mania)

Simon GE. Social and economic burden of mood disorders. Biol Psychiatry. 2003;54:208215. [PubMed]

Solomon P, Draine JE, Mannion E: The impact of individualized consultation and group workshop family education interventions on ill relative outcomes. Journal of Nervous and Mental Disease 184:252-255, 1995.

Stanton B, Baldwin RM, Rachuba L. A quarter century of violence in the United States: an epidemiologic assessment Psych Clin N Am. 199720269-282 [PubMed]

Stefos G, Bauwens F, Staner L, Pardoen D, Mendlewicz J. Psychosocial predictors of major affective recurrences in bipolar disorder: A 4-year longitudinal study of patients on prophylactic treatment. Acta Psychiatr Scand. 1996;93:420-6. [PubMed]

Tardiff K, Koenigsberg HW (1985) Assaultive behavior among psychiatric outpatients. Am J Psychiatry 142:960-963

Tardiff K, Sweillam A (1980) Assault, Suicide and Mental Illness," Archives of General Psychiatry, 37:164169, 1980)

Tardiff K, Sweillam A (1982) Assaultive behavior among chronic inpatients. Am J Psychiatry 139:212 215

Van Snellenberg JX, de Candia T. Meta-analytic evidence for familial coaggregation of schizophrenia and bipolar disorder. Arch Gen Psychiatry. 2009 Jul;66(7):748-55.

Walker Z, Seifert R (1994) Violent incidents in a psychiatric intensive care unit $\mathrm{Br} \mathrm{J}$ Psychiatry 164:826-

WHO-Qol Group. The World Health Organisation Quality of life Assessment (WHOQoL): development and general psychometric properties. Soc Sci Med 1998;46:1569-85.

WHO-Qol Group. The World Health Organisation Quality of life Assessment (WHOQoL): development and general psychometric properties. Soc Sci Med 1998;46:1569-85.

World Health Organization (2004). The global burden of disease: update. Part 3: disease incidence, prevalence and disability.

http: //www.who.int/healthinfo/global_burden_dis-ease/2004_report_update/en/.

How to cite this article: Ashok. S, A Singh (2017). Family Interaction Pattern and Quality Of Life of Caregivers Having Violent Patients with Bipolar Affective Disorder (Current Episode Mania). International Journal of Indian Psychology, Vol. 5, (1), DIP: 18.01.126/20170501, DOI: 10.25215/0501.126 